\title{
Cartography of an Event On the Visuality of the Map in (Neo)Conceptual Art
}

\author{
Ján Kralovič
}

\begin{abstract}
The article deals with the map as an image whose visuality within the framework of conceptual artists claims a strategy or a map image based upon the records of their activities. Maps are not understood as objective, technical transcriptions of topographic structures, but in relation to artistic production - as records of creative presence and subjective perception, recording locations and their specifics. Maps represent a scene where disparate elements are brought together and form an image of a particular state of knowledge. In this text the use of maps is analyzed on two basic levels: a) the map as a result (record) of a mental or physical process, and b) the map as the documentation of an activity that was part of spatial practice in a specific territory. Selected examples of artists and their works are given, based on a conceptual (appropriation, dematerialization, concept / idea accentuation) character during the period of the 1960s through the 1990s (namely M. Šejn, D. Tóth, L. Ďurček, R. Matuštík, M. Maur, and M. Adamčiak) with forays into contemporary neo-conceptual strategies (such as those of J. Pfeiffer).
\end{abstract}

KEYWORDS Map, conceptual art, visual culture, walking

If something hurts me, I erase it from my maps. In them, places where I stumbled and fell, where someone walloped me or cut me to the quick, have ceased to exist. In this way I have already erased several large cities and one whole province. Eventually I may erase the whole world. Maps accept this with compassion; they miss white spaces, which were their happy childhood. (Tokarczuk 2008: 79)

As a child, I would often trace over the detailed maps that my father, a surveyor, brought home from work. The thin contour lines, positioning points, elevations, and areas in multicoloured geometrics or hatching, all creating an organic impression, fascinated me. They brought a motif of technical drafting, of symbols and numerical codes together with pictorial drawing, all while stimulating a fantasy image of the territory the map depicted. At this young age, I would take part in field measures through the flat country of southern Slovakia, where my task was to hold tenaciously on to the sighting rod sticking perpendicular to the

Sociálni studia. Department of Sociology FSS MU, 1/2015. S. 9-30. ISSN 1214-813X. 
earth's plane. This moment of "Thoreau-esque" walking ${ }^{1}$ as a way to get to know the land, or the memory of a child outlining a map on tracing paper, is not intended as sentimental reminiscence - rather it is a clarification, pregnant and to the point, of the incentive for addressing the visuality of the map. It was the motivation for resolving to work with the topic of the various modes and strategies for utilizing the map, plan or atlas in art, and specifically conceptual art. ${ }^{2}$

It is the nature of conceptual art to stress the idea underlying a work of art. The material side, or workmanship, of the rendering is often underplayed. A strategy of appropriating existing objects and schemas is applied, using reproduction techniques and symbol systems of scientific (i.e. exact) disciplines. The map as cartographic record of territory represents this kind of system, able to communicate an event even with regard to its specific location. The map in the main documents the character of a place, and graphically models how a spatial arrangement is expressed. In art cartography, subject to no strictly exact rules, the map becomes a platform for recording ephemeral events, subjective interventions by the artist, and even using the map's visual structure to create a new schema, representing fictive, subjective or utopian space. In his experimental text Species of Spaces the French author Georges Perec writes:

I would like there to exist places that are stable, unmoving, intangible, untouched and almost untouchable, unchanging, deep-rooted; places that might be points of reference, of departure, of origin... Such places don't exist, and it's because they don't exist that space becomes a question, ceases to be self-evident, ceases to be incorporated, ceases to be appropriated. Space is a doubt: I have constantly to mark it, to designate it. It's never mine, never given to me, I have to conquer it (Perec 1997: 91).

This thesis of conquering, of appropriating territory through the map concept, is one of this study's key purposes. Using the map to mark and occupy a defined territory is also a way of connecting an artist's thinking with the principle of cartographic generalization.

\section{Definition of theme}

In recent years a number of extensive exhibitions have been mounted, accompanied by text catalogues, treating the topic of art cartography. In Mapping and Contemporary Art, the Australian artist Ruth Watson notes that from 1977 to 2009 significant institutions in the U.S., Europe and Australia alone hosted 24 exhibitions focused on artistic map production (Watson 2009: 293). In the (Czech and) Slovak milieu the topic has not been explored as much. In 2011, in spaces at the City Gallery of Bratislava and the Slovak National Gallery, Daniela Carná and Lucia Gregorová-Stachová conceived and curated the exhibition Maps: Art Cartography in the Centre of Europe 1960-2011; it reflected on work by artists using the visual image of the map in the wider Central European region (Čarná and Gregorová 2011).

1 Here I refer to the American poet, surveyor, wanderer and founder of the nature writing genre, Henry David Thoreau (1817-1862), and above all his short book, Walking.

2 The starting point for this study was content from two exhibition catalogues: Storr (1994) and Bianchi-Folie (1997). 
The term "art cartography" is broad, and is employed frequently. Therefore it seems necessary, for this study's purposes, to select for this text two key means of handling the image of the map: (a) the map as stimulus to interpret an image, as artistic appropriation and intervention in the map's plan, as animation of a map (from the Latin animó, to breathe life into, to transmute, endow with spirit or disposition); and (b) the map as projection of physical experience, walkers' maps, the map as record of moving in a city, of walking.

The study is divided into two chapters based on these two strategies: (1) Maps drawn via walking, and (2) Maps as records of psycho-physical events.

The first chapter gives attention to the map as a visual structure. Maps created as works of authorship "ex post," after the artistic experience arises as a record of events that took place. The visuality of maps is appropriated, but the result is an inherent, artistic map, which is not indicative of standard maps as universal cartographic illustrations.

The second chapter deals with works that make use of existing maps. The cartographic image is used in the form of an appropriation, as a "readymade." The artistic activity is simply various additions to the map (drawing of lines, designation of important sites and acts, drawing of a path, wandering). The legend becomes important here, as it highlights the activity. Equally important is the choice of location, the territory which the map represents. This location often has strong ties to the life and work of the artist(s). In the first part, the map is the result of an actor's activity; in the second chapter, the map exists beforehand and is appropriated, serving as a factual and "unaesthetic" documentation.

Where I refer to artistic activity, I understand it to mean a structured sequence of events and actions, physical and mental acts, with the use of material or one's own body material, made "here and now." In the individual actions, the present is emphasised, and the map becomes a documentary record, a concept of the event and its action conveyed to the audience.

From this perspective, it is important to clarify several key terms. According to Stručný lexikón kartografie (A Short Lexicon of Cartography), a map is defined (both "selectively" and "generally") as "a graphic expression of objects or phenomena, or their characteristics, in a space, prepared as a graphic model that is accurate schematically or in reality, in appropriate scale and cartographic illustration" (Pravda 2003: 79). Simply put, a map is a symbolic image of geographic reality, showing select characteristics, and intended for use where spatial relationships are of primary importance. Cartography is the science of creating and utilizing such maps.

From the perspective of artistic production, an exact definition is less essential than the use of visual codes and symbol systems, and the map's aesthetic qualities as conditioned by associative artistic imagery. Maps imply various means of representing reality, and various qualities: as semiotic systems, as visual objects, as strategic plans, as representation of territorial dominance and power, etc. As J. B. Harley notes in his study Maps, Knowledge, and Power, maps can never be seen as neutral depictions; they represent a mode of perception, expression and structure of the human world (Harley 2008). Maps are depictions deformed, comprising a projection of a topographic environment as well as the territorial imperatives of a particular political system. Indeed, maps can be doubly deformed: first because of topographic projection of real territory onto a flat map image, and second in case of intentional 
manipulation based on power or being watched. ${ }^{3}$ The map can thus become an ideological instrument, as a discursive political "commission."

In the aforementioned text on describing the ideology of maps, Harley notes that they are an altered form of the known, a form of language that records a certain event. Yet at the same time they are analogous to rhetorical images. They are bound by rules that govern their codes, and are delineated by means that society has created, adapted and utilized. Thus maps are an influential form of discourse (Harley 2008: 186-187). At the same time, the map is a form of conceptual depiction, in the sense of building an internal thought image based on a project, a cartographic projection. Thanks to the technical image as a concept, there arises a stimulation of one's own mental and process activities. The modern map is a technical image in the meaning that Vilém Flusser defines. It is a projection that can be decoded not on the basis of the significant, but rather on the signified; not on what it indicates, but rather on the direction towards which it indicates. The cartographic image is thus a vector, showing the way to something outside itself, to an event that is only recorded within it and noted down as a concept.

"Project documentation," which started receiving attention in certain areas of artistic production in the early 1970s, is connected with the conceptualization of art. As the American theoretician Lucy R. Lippard put it succinctly, "Conceptual art, for me, means work in which the idea is paramount and the material form is secondary, lightweight, ephemeral, cheap, unpretentious and/or "dematerialized"' (Lippard 1973: 7). Thus, a map is the relationship between the verbal and physical (sensory, bodily, visual) experience.

For the purposes of this text, I characterize conceptual art as artistic production that does not accent form and material qualities, but rather idea and meaning. Far from defining itself within the anchoring of a medium, it constantly attacks the very segmenting of art into genres. ${ }^{4}$ Conceptual work does not serve to produce artefacts, but rather to restructure thought. It puts its audience in a position wherein perception (experience, interpretational habits) is questioned. ${ }^{5}$ In conceptual art, the accent is on the course of events, the sense of a gesture or an action. Place, and the spatial context of realization, also has enhanced meaning. It is recorded by means of technical images (photography, plans and maps), brief written notes, and outlines or sketches. This mechanism is directed toward replacing artefact with a projective or linguistic form.

Art cartography takes on various forms, as a planimetric projection system guided by rationality and science is enhanced through the artist's invention and fantasy. Using maps in

3 The American geographer Mark Monmonier addresses both forms of map-based "lying" in detail in his book How to Lie with Maps (cf. Monmonier [2000]).

4 Tony Godfrey maintains that conceptual is in part an ever-present question on the essence of art (cf. Godfrey [1998:4]).

5 The Czech philosopher Petr Kotátko, in his article Umělecké dílo konceptuální, also understands as conceptual those pieces that "attack our concept apparatus along with further parts of our cognitive (or in some cases practical) equipment... intervening in its operation, preventing it from getting going in the usual way, or switching between its possible modes, thus revealing its limits" (Kot'átko 2011: 44). 
visual art is an exceedingly exemplary joining of approaches both precise and imaginary. The map appeared in $20^{\text {th }}$-century art through various strategies: from citation (e.g. G. de Chirico, The Melancholy of Departure, 1916; R. Haussman, Tatlin at Home, 1920), fiction (Surrealist Map of the World, 1929; M. Ernst, Europe After the Rain, 1933), and artistic appropriation (M. Duchamp, Farewell to Florine, 1918; Y. Klein, Globe, 1957; P. Manzoni, The Base of the World, 1961), through material and installation adaptation (C. Oldenburg, Soft Manhattan \#l and \#2, 1966; Luciano Fabro, Road Map Italy, 1969) and utopia (G. Maciunas, Ginger Island Map, 1969; S. LeWitt, Map of Amsterdam, 1976), to maps as records of a process or event of motion (R. Smithson, Map for Double Nonsite, 1969; N. Holt, Buried Poems, 1971), or as physical occurrences in landscape (R. Long, October, 1969; D. Oppenheim, Annual Rings, 1968).

Given this text's theme, I have primarily emphasized the map in its potential conceptual depiction. As already mentioned, the map is itself a conceptual image, because of how it is conceived and vectored, where its meaning lies outside its depiction. I give precedence here to the map as a record of a process, a physical situation, an artist's process and situational practices, a reference to an action undertaken. The map is a visual emblem of an event's cartography.

\section{Maps drawn via walking}

Walking is one of the most basic processes involved in getting to know an environment. It is an activity of contact, a processual "sensing" of the city's or countryside's form. The map is frequently a guide for wandering, an irreplaceable aid for finding the way in unknown territory. But a map can also be created based on physical movement, on bodily experience as the result or outcome of a given process.

In his text Walking in the City the French philosopher Michel de Certeau makes a theme of everyday walking activity as an act of communicating and acquiring knowledge, emphasizing a relationship analogous to speech (Certeau 1984). In Certeau, walking is understood as a form of significant process, a "footprint" written in a spatial field and uncovering the intertextuality of an urban "body," i.e. an environment forming the structure and form of a city. It is the "poetry of the everyday," an asyndetic interconnection of various realities that depend on one's viewpoint and location, conditioned by the very process of walking. Through a series of detours, reversals and short cuts - not respecting the spatial limitations of paved roads and paths - walking resembles a literary text, corresponding to phrasing or stylistic symbols. One could point to a relationship where walking is to the city's urban system as discourse (parole) is to language (langue).

Walking, vis-à-vis the system and strictness of urban roads and paths or the guiding points in the countryside (such as marked hiking trails), is a unique, individual process, a variation. The anthropologist Marc Augé gives an interesting example of this in his book An Anthropology for Contemporaneous Worlds. In it he notes the research of the French psychologist Georges Vignaux, based on an experiment with four groups of three individuals who did not know Paris and on their way had to inquire of pedestrians they met. Their goal was Rue Mouffetard, and there were four starting points: Palais Royal, the Bastille, and two metro stations, Sèvres Babylone and Denfert-Rochereau. The results showed that the 
routes recommended were not necessarily the shortest, but rather those that could most easily be explained and understood (Augé 1999: 111-112). The routes comprised elements that seemed natural to those who were giving directions, who hoped that it would also seem obvious to the recipients. Thus the routes consisted of a speech dimension: not just landmarks, but such landmarks as were understandable to the speaker. According to this meaning, walking is a practice of subjectively "mapping" the space of a city or a selected territory. As Certeau writes, "The walking of passers-by offers a series of turns (tours) and detours that can be compared to 'turns of phrase' or 'stylistic figures.' There is a rhetoric of walking. The art of 'turning' phrases finds an equivalent in an art of composing a path" (Certeau 1984).

Certeau's text on "walking," which is part of his book The Practice of Everyday Life, published in English in 1984, results from a desire to escape panopticism as defined by Michel Foucault (Foucault 2004). In his Discipline and Punish, Foucault understands a panopticon as a system or diagram of the power mechanism, which is not just a matter of buildings or institutions but could even be the very structure of the city. The city's urbanism, which is part of its spatial systematization, is a certain kind of implementation of bodies in space, an allocation of individuals within their mutual relations, a hierarchic organization. Thus, based on the spatial allocations of its components, the city can become a panopticon, an intensifier of the supervision of power, assuring the control and direction of its citizens (Foucault 2004: 206-207). Certeau is conscious of this urbanizing language of power, but also cautions that the city walker need not strictly keep to delineated routes, but rather can turn aside from them, rebelling against the system. Walking can thus be seen as a way of freeing oneself, of liberating oneself from (repressive power) structures.

Returning to the "rhetoric of walking" as a specific individualizing accent, which subjugates spatial fields, naturally occurred long before Certeau's analysis of everyday practices. Wanderers, travellers, nomads and flâneurs are stock figures, representing escape from being fixed in one place, emblematic characters creating their own maps. In their rendering, walking manifests itself as a specific process, a "psychogeography," which becomes the study of practical environmental influences on one's behaviour, the discovery of an environment's changeability (Ungar 2004: 371). It was the situationists who more than anyone developed a method of "drifting", of getting to know a city psychogeographically by implementing walking-based surrealistic methods of psychological automatism; they were drawing on analysis of the urban environment. For the situationists, getting lost was a basic instrument of liberation, for getting the emotional effect of a known and familiar environment by accenting its impermanence and transience.

The poet and leading ideologue of the situationist movement, Guy Debord, in the second issue of Internationale Situationniste in 1958, introduces a broad interpretation of the theory of dérive (English: drifting) as "a technique of rapid passage through varied ambiances... one or more persons during a certain period drop their relations, their work and leisure activities, and all their other usual motives for movement and action, and let themselves be drawn by the attractions of the terrain and the encounters they find there" (Debord 1958).

In 1957, Debord made several psychogeographic collages from cuttings of Paris maps (Naked city, 1957; Discours sur les passions de l'amour, 1957). They represented direct and goalless wandering through the city, in an endeavour to deconstruct the map's usual functions. 
Figure 1: Guy Debord, "Naked City”, 1957

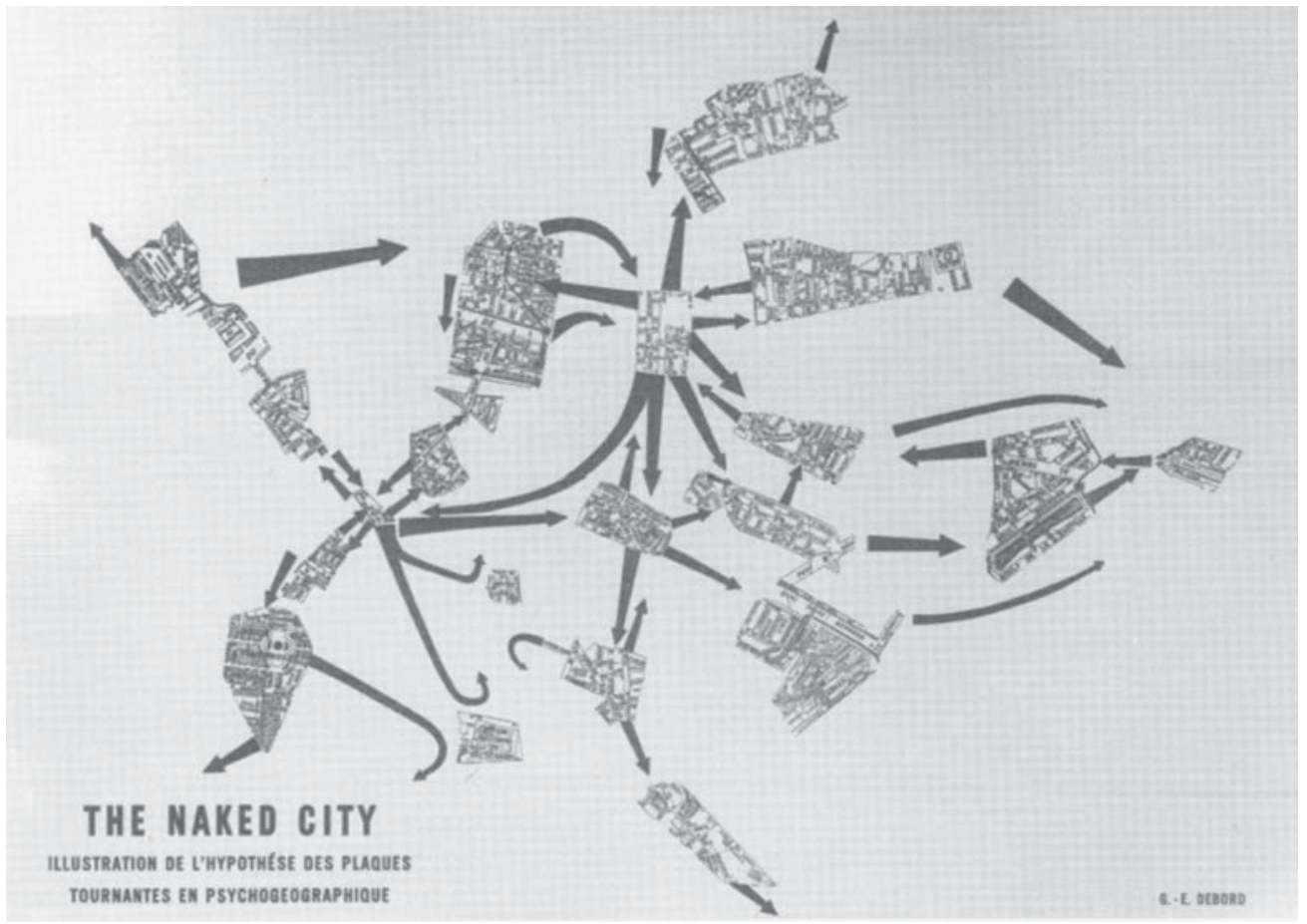

Source: Sadler (1999: 60)

For Debord, the map became an anticipation of the process itself. It no longer records, but rather instructs the user. It is a subversion of the traditional plan of the city, just as situationist texts, collages or comics are a criticism of a commodity-oriented society that demands spectacularly saturated images. The map no longer copies a territory, but becomes a new territorial practice. ${ }^{6} \mathrm{~A}$ stroll becomes an expressive and semantic medium for situationism to rescue the public from passivity, from the hackneyed pathways of (urban) conventions, through the method of deviation (Fr. détournement). The détournement strategy is defined as a deviation from existing aesthetic elements. It implies a coming together in artistic production,

6 This model in essence criticizes the society of the spectacle, to which Guy Debord applies the map metaphor in the sense of projection: "The spectacle is a map of this new world - a map drawn to the scale of the territory itself" (Debord 2006: 23). Thus, in Debord's collage of maps the issue is not just the breaching of the conventional spatial and urban arrangement, but also the reference to the disturbing of an unambiguous image or projection. In his book Simulations (1983), Jean Baudrillard built on Debord's map metaphor and strategy, writing that territory is not the precursor of a map, but rather at this point the map makes territory possible (Baudrillard, Jean: Simulations. New York: Semiotext(e) 1983, p. 2, cited in Best and Kellnes 2008: 84). 
contemporary or period, forming a higher constitution of the environment (Magid 2008: 37). In this sense, there is no situationist painting or music, only situationist use of these media; situationism is thus a method for instruments of reshaping the environment, even at the cost of disruption or chaos.

There is a kind of rhizomatic structure in the situationist map, the map as puzzle (cf. J. Johns, Map [Based on Buckminster Fuller's Dymaxion Airocean World], 1967), or associative juxtaposition of map elements (cf. Constant Nieuwenhuys, New Babylon, 1969; S. Pinczehelyi, Can You Tell Me Where the Fisherman's Gate Is I, II, 2011).

A rhizome, as Gilles Deleuze and Felix Guattari explain in their book A Thousand Plateaus, has some features analogous to maps. ${ }^{7}$ Deleuze and Guattari construe the map as the opposite of the index. They understand it as a structural grid, as testimony that is open and thus capable of being continually supplemented and modified. Maps likewise activate only once they are owned and used to walk and dwell in a place, just as language is activated through speech and discourse. Deleuze and Guattri, on the analogy between rhizomes and maps, write: "The rhizome... is a map and not a tracing... What distinguishes the map from the tracing is that it is entirely oriented toward an experimentation in contact with the real. The map does not reproduce an unconscious closed in upon itself; it constructs the unconscious" (Deleuze and Guattari 2005: 33). In the examples given, the rhizomes find fulfilment as an open, linkable, removable and endlessly modifiable structure.

Naturally, the cartographic map is always constituted on the basis of geographical reality, in the case of city maps on urbanism. Urban structure is a rationally-designed system. Urban planning has different forms: rectangular (the cardo-decumanus system), concentric (central) or polycentric. The city is a partially controlled system, subject to urban, architectural and engineering criteria and design. Nevertheless, it contains within itself a certain spontaneity, with possible violations of the defined networks. Unauthorized construction, additions and demolitions, passages and short-cuts - these are all elements that a map depicting radials of roads and residences may fail to represent thoroughly. For the city, relationships between topographic elements and micro-cartography are also important. I understand the analogy of the map and rhizomatic structures in the context of these subversive, unconscious processes that disturb the urban plan, "escaping" from the generalized cartographic image. A map, despite being a fixed image, provides for the possibility of heterogeneous, non-directed, "unconscious" movement.

The examples of maps I have noted emphasize this pictorial modifiability.

7 Gilles Deleuze and Félix Guattari make use of the biological term rhizome (transformed subterranean axis, underground, root). Deleuze and Guattari maintain that a map has a rhizomatic structure, as there are many places through which one can come into it. We can make a link from any point of a map to any other point. Its structure is interwoven and continual, like that of a root structure. 
Figure 2: Rhizome. Convallaria multiflora

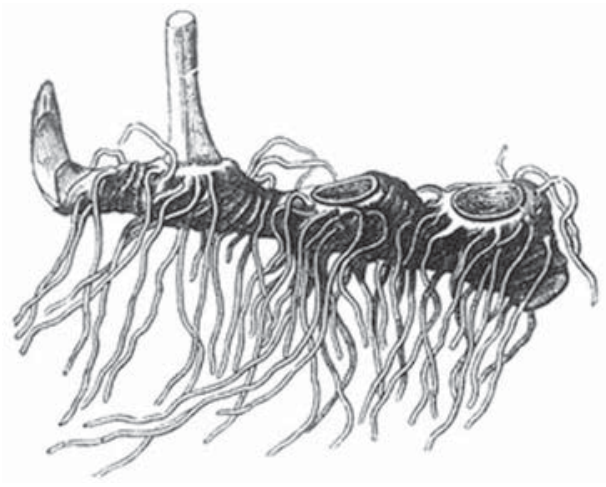

Source: http://www.deacademic.com/

Figure 3: Costant Nieuwenhuys, New Babylon, 1969

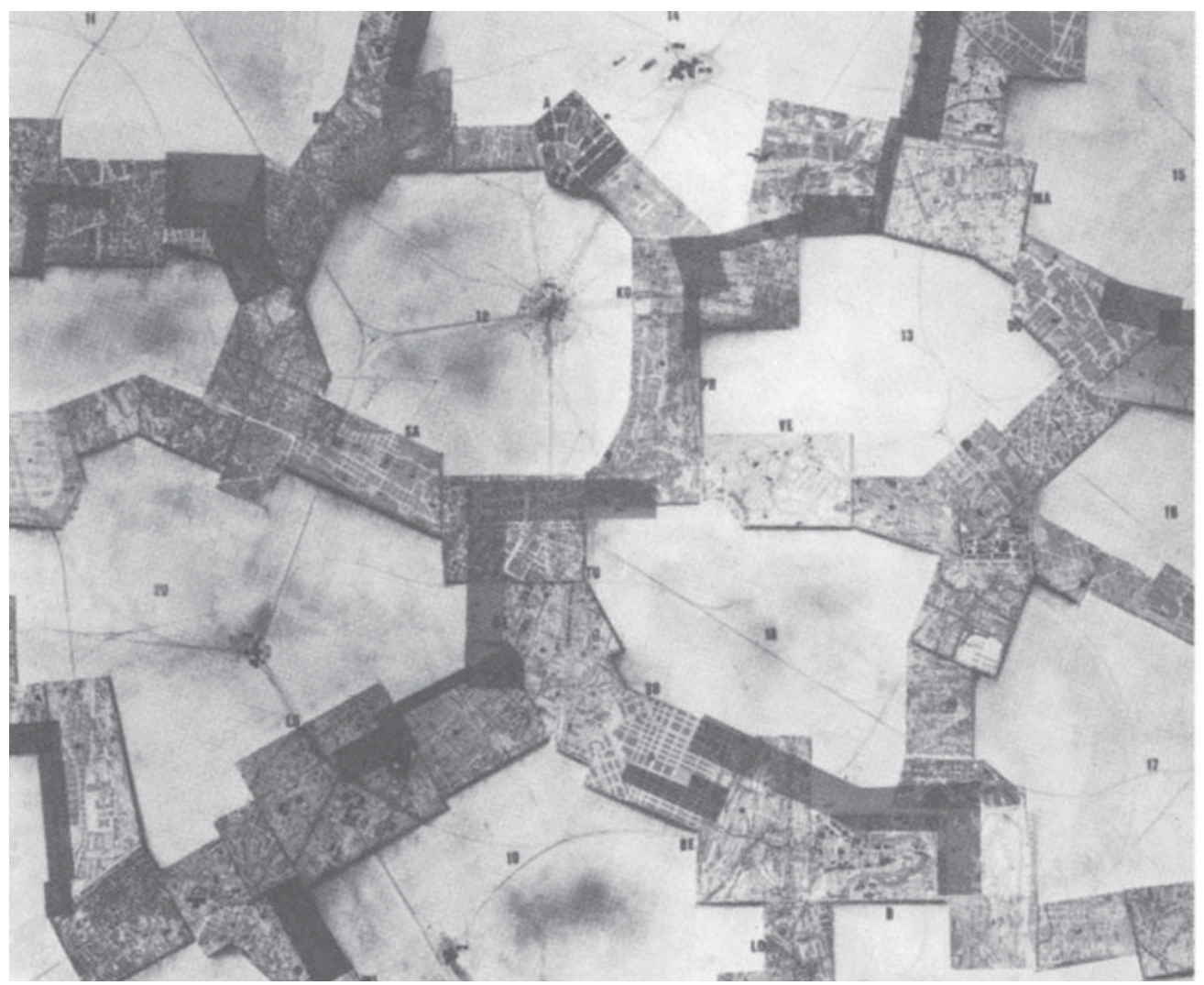

Source: Ohrt (1990: 124) 
The project Vychádzkové básne (Strolling Poems, 1973) by Dezider Tóth presents the subjective situational map as a concept (like every map, bringing together the dimensions of space and speech). Tóth recorded the routes of his walks through Prague during his compulsory military service on cuttings from a map. These little maps, glued to cardboard, are a graphically-visualized record from a soldier's furlough booklet. The project has elements in common with graphic music scores and visual poetry, and with the destatic poetry in Jiři Kolář's Návod $k$ upotřebeni (Instructions for Use) and Ladislav Novák's Básně pro pohybovou recitaci (Poems for Recitation in Motion). In the context of this study, the action becomes one with reality, with nothing setting it apart. Metaphor occurs only afterwards, as the clippings are made, causally contextualizing the walking by recording it on the map's schema. The map serves as a reciprocal image used to facilitate a specific experience and conscious localization of territory, which for the artist becomes a momentary liberation during a time of military drills and discipline. Tóth tries to playfully transform this condition

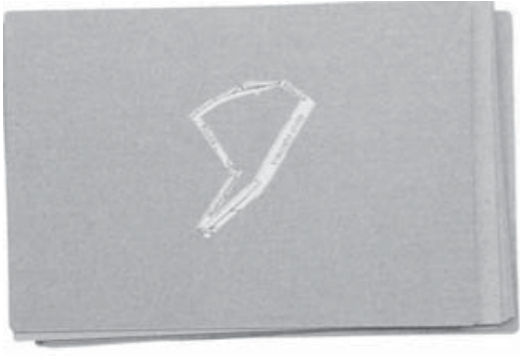
using his "cartotheque of strolls." His position takes

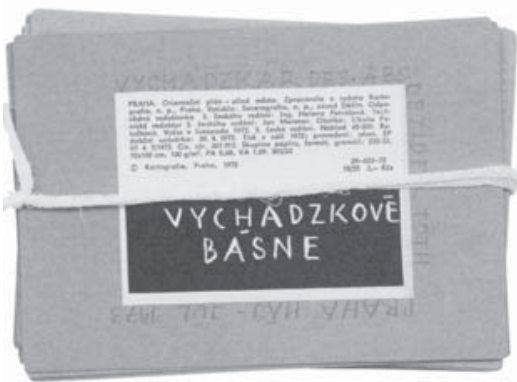

Figure 4: Dezider Tóth, Strolling Poems, 1973. Source: Artist's archive into account what the conceptual artist Joseph Kosuth formulated as artistic inclination, when in 1969 he wrote that the language forms used by the artist to frame his propositions are often "private" codes or languages, and that this is an inevitable outcome of art's freedom (Kosuth 1991). Dezider Tóth's "visual texts" come out of the tradition of music scores and instructions. They document the artist's interest in process, in ephemeral experience, which subsequently becomes fixed into a minute artefact (the artist's book) as a pictorial schema of event. An analogy to Tóth's "limited" or constructed maps might be the slightly older work of the Polish artist Ludmila Popiel Found Objects (1972), in which she displayed photographs of random found objects with miniature maps showing their location. The piece is a kind of diary, systematic evidence of chance discoveries. A tension thus arises between the unforeseeable moment and the objective form of the cartotheque.

Until now I have noted art maps drawing on the urban setting, and now I will turn to walking maps related to natural territory. A fascination with the rural environment is an enduring impulse for the work of the Czech artist Miloš Šejn. Thoreau's faith in the gentle magnetism of nature, which - if we consciously allow it - leads us in the right direction, is highly pertinent to Šejn's work, which is about the adaptation and formation that takes place upon accepting and coming in contact with nature. The art historian and theoretician Jiří Valoch said of Šejn: "All the means he uses lead us to the supposition of nature as a phenomenon, and to how man can perceive nature, react to it, let it affect him, and through momentary 
interventions become part of it, enter into it" (Valoch 1986). In the journalized Cartographic Studies (1969), Šejn documents where he lived in nature; it is field research using his own maps as traced onto transparent paper, then layered and overlapped. This results in a kind of meta-map, overlapping fragments of many territories, which like a palimpsest multiplies and creates a personal atlas of the artist's contacts with natural elements. These were often actions without participants, based on minimalist gesture, an ephemeral intervention (touch, displacement, shifting), that imperceptibly but permanently altered the countryside.

Figure 5: Miloš Šejn, Cartographic Studies, 1969

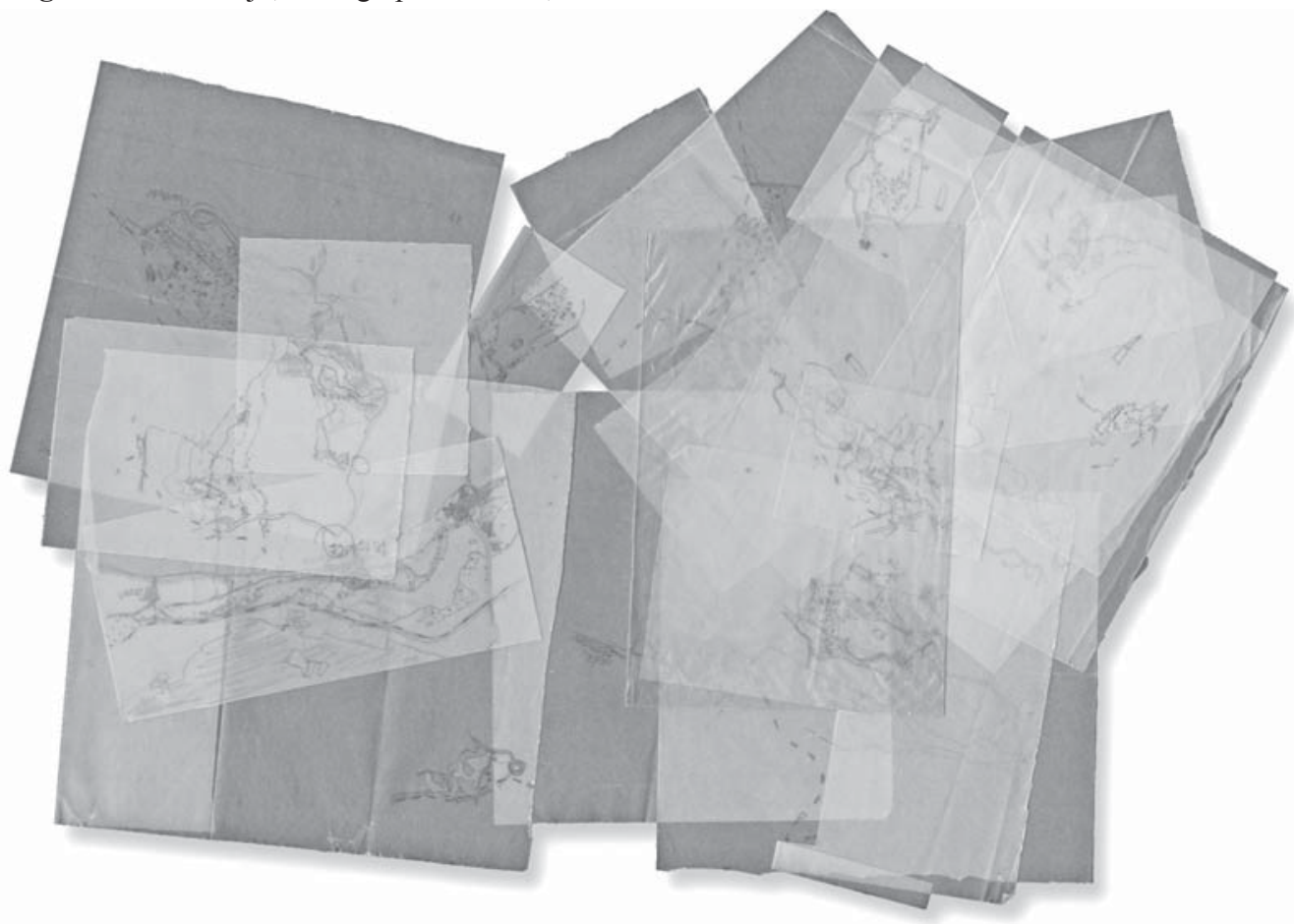

Source: Artist's archive

The map as an art form for recording action appears in the work of musicologist, musician and conceptual artist Milan Adamčiak. In Chodecké kusy, Liptovská séria, (Hiker's Pieces, Liptov Series, 1960s, drawing: 2009) he builds on the visual "mapped" musical scores of John Cage (Fontana Mix, 1958; Atlas Eclipticalis, 1961-62). In a cycle of cartographic drawings, Adamčiak wrote instructions for acoustic/motion activities for participants in possible walks around sites in the Liptov region. The drawn maps are supplemented by a legend marking motion and sound instructions related to specific places. Adamčiak's drawings evoke hiking trails and tourist routes. In his case, they are a call to a complex synesthetic activity, intermingling physical and musical activity, an instrumental/phonic element and a perceiving of surrounding impulses (like the density of civilian or tourist activity). 
Figure 6: Milan Adamčiak, Hiker's Pieces, Liptov Series, 1960s (drawing: 15. 07 2009)

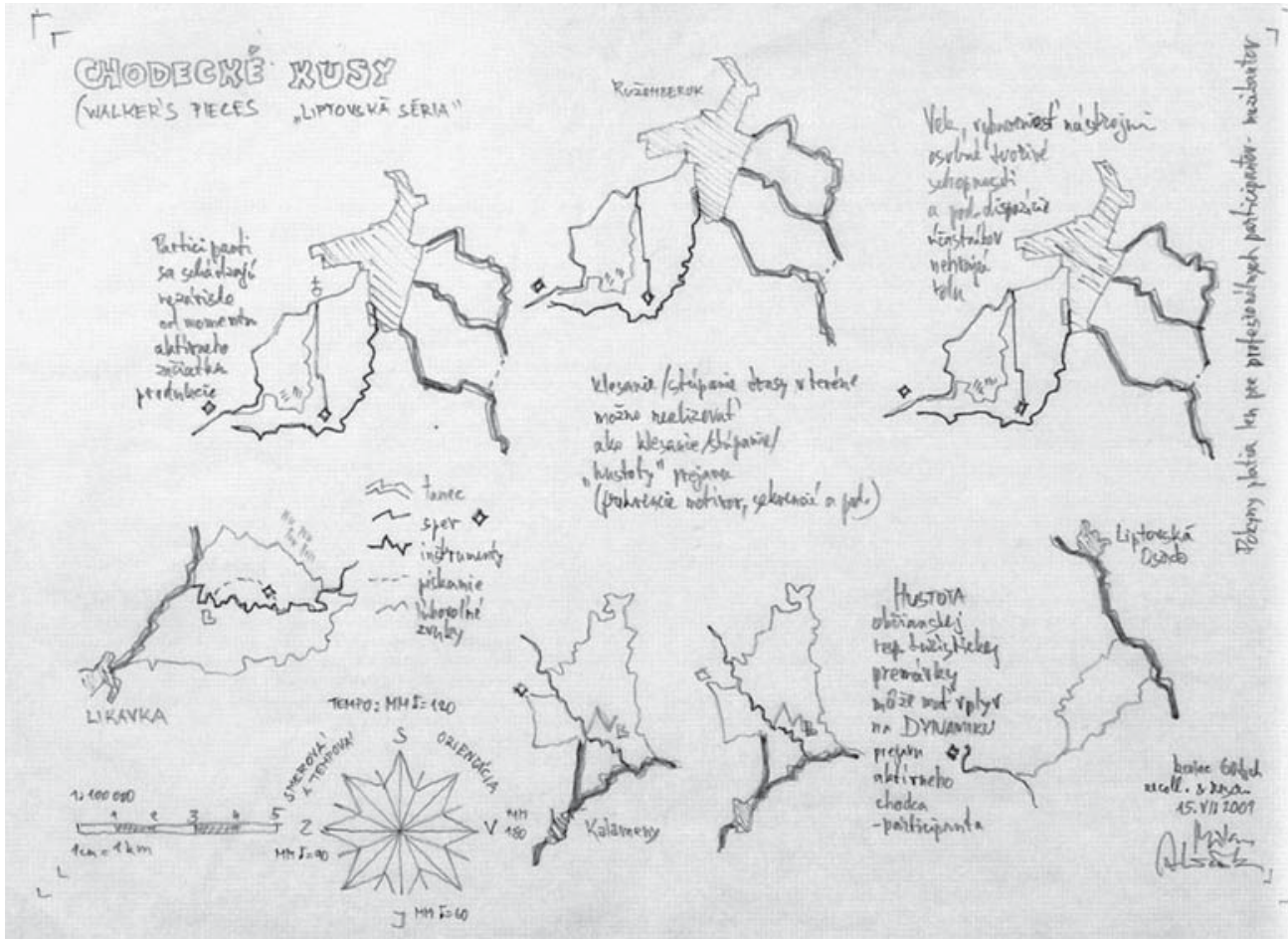

Source: Private archive

The Czech artist Jan Pfeiffer, in his piece Skratky (Shortcuts, 2007), is one of the younger artists working with the principle that walks create new pathways in the urban environment. This artist gives his attention to routes that acquiesce to no organized and constructed lines of communication, instead forming through long-term, well-worn pedestrian activity: the short-cut. Using the internet satellite search engine Google, he mapped the world's greatest metropolises, with the outcome being the finding that short cuts occur predominantly in posttotalitarian countries. Based on the artist's on-site research, it can be said that the paved roads and walkways in these locations do not reflect the population's natural movement through space. Rather, they are the consequence of geometric urban plans, which mean nothing to the pedestrian's strategy of seeking the shortest and most straightforward "distinct" path. Shortcuts are a minute urban revolution by the city structure's users: pedestrians. They are a way of looking for a new form, an escape from a system of organized life practice: the routing of the body's movement in town. The outcome is an idiomatic "bodily" upheaval, an overcoming of the ideological conception of steered control, a psychogeographic breaking point of appropriating the city's structure. This anonymous practice creates an interlacing network of trajectories as a corollary to handwriting, plotted into a linked urban structure. With their very 
bodies, pedestrians are transforming space, which becomes tangibly or kinesthetically appropriated. In making these practices visual, Pfeiffer revives Michel de Certeau's thesis from Walking in the City: the language of power may be urbanizing, but the city is abandoned to opposing movements that occur and interconnect, even beyond the reach of panoramic power (Certeau 1984).

Figure 7: Jan Pfeiffer, Shortcuts, 2007
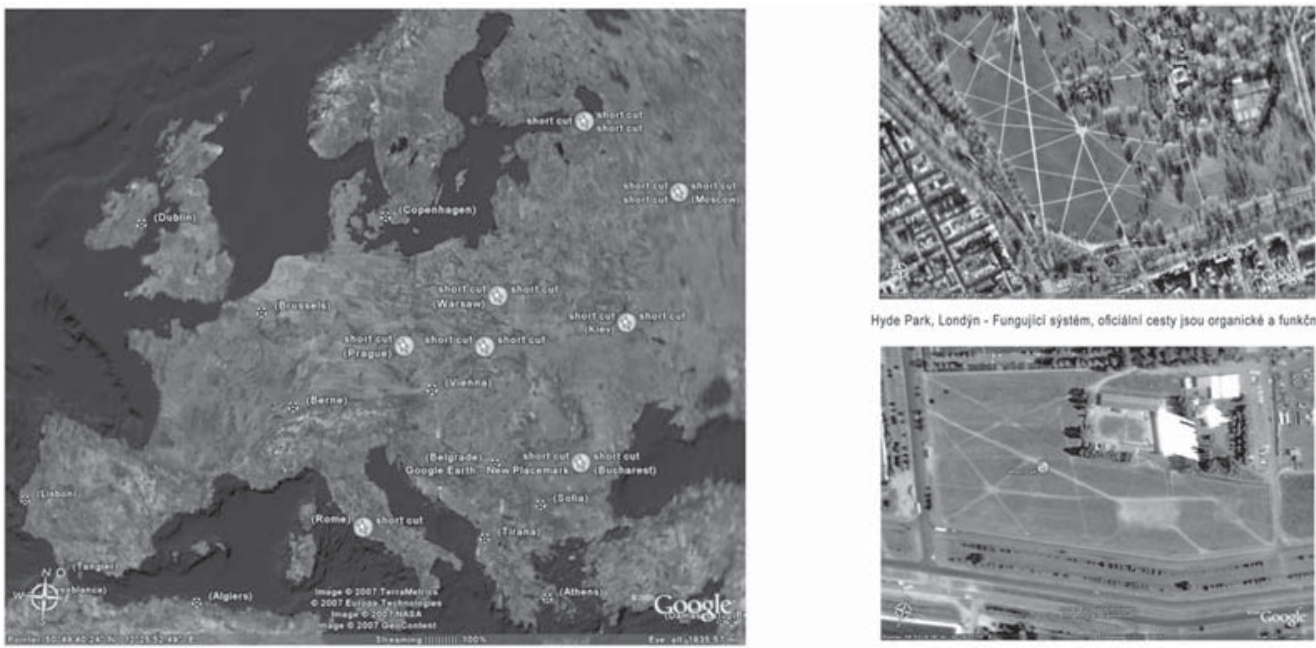

Sant Petersburg - nefungujici systim, positotalital zemb, nuthost Short cuts

Source: Artist's archive

\section{Maps as records of psycho-physical events}

Another approach - besides the creation of artists' maps based on handwork, copying, painting-over or collage fragmenting - is the use of actual cartographic maps as a scientific image, into which an event or course of action is simply recorded, by drawing on it or otherwise making a statistical statement. The Slovak conceptual artist L'ubomír Durček is one who works with such desubjectification of the map as a form of documentation. In many ways, his actions refer to a motif of observation (recording) or walking, emphasizing a communicative, appellative function.

On 19 July 1972, Durček made a record of all the people that were running through the centre of town where he happened to be on his daily commute between his home and work place. His photo-collage of this event, Evidencia - 85 eventov $v$ Bratislave (Evidence of 85 Events in Bratislava), presented a map of Bratislava along with precise timings of running individuals. This random (though not unusual) situation on the street thus became the subject of private research, with the artist's subjective preferences eclipsing the lack of exactitude and scientific method, his own movements in the city being subject to his dwelling 
place and perceptions in observing his surroundings. Ďurček's way of observing and recording (un)usual movement can also be seen as a "spectator's" participation in a performance, for which the stage is the street itself. Public space is an environment for social contact, in which various relational and situational activities become "role" playing (Goffman 1999).

Figure 8: L'ubomír Ďurček, Evidence of 85 Events in Bratislava, 1972

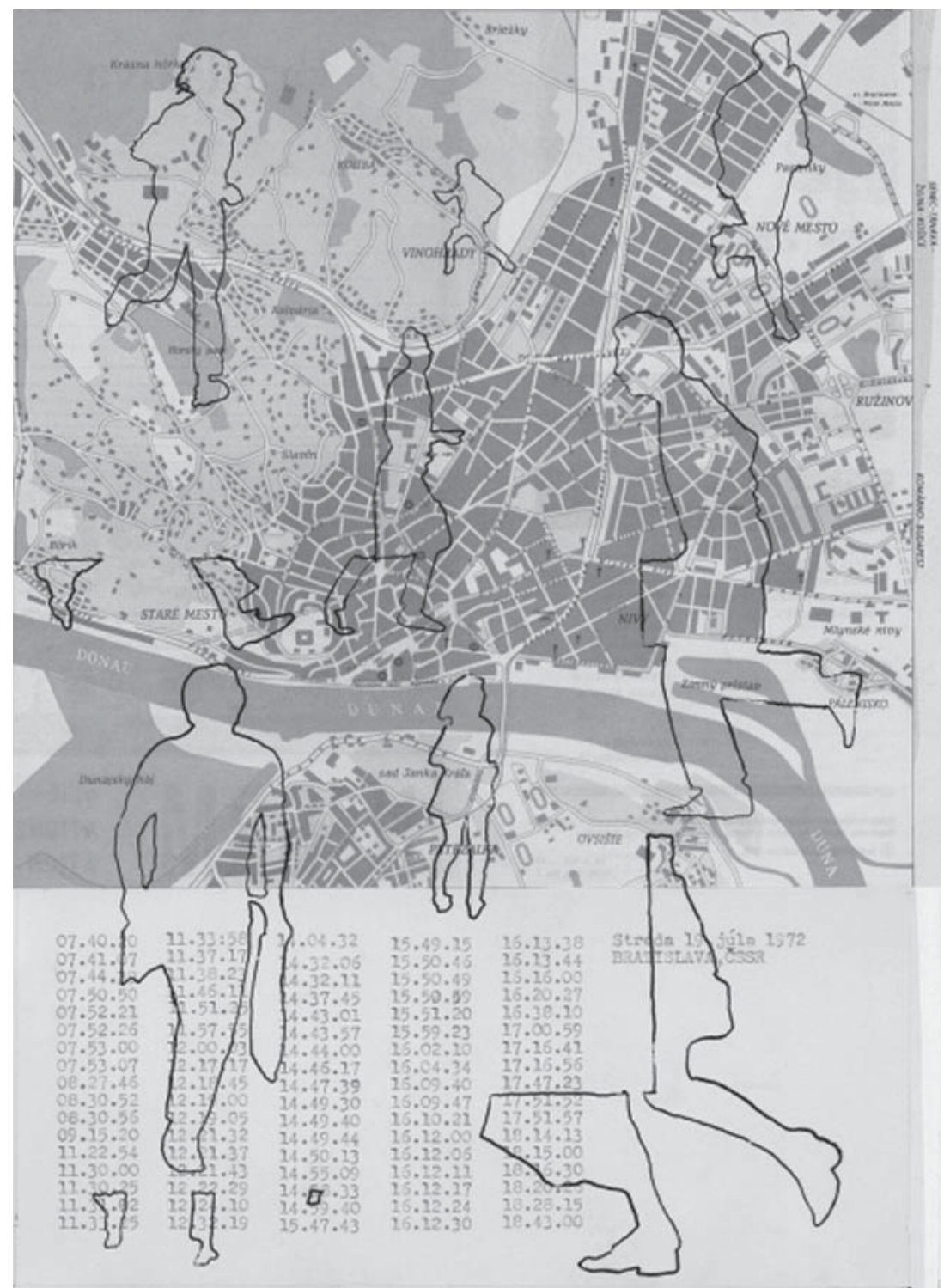

Source: Artist's archive (photo: Dana Illeková) 
Figure 9: L’ubomír Ďurček, Walk, 1976

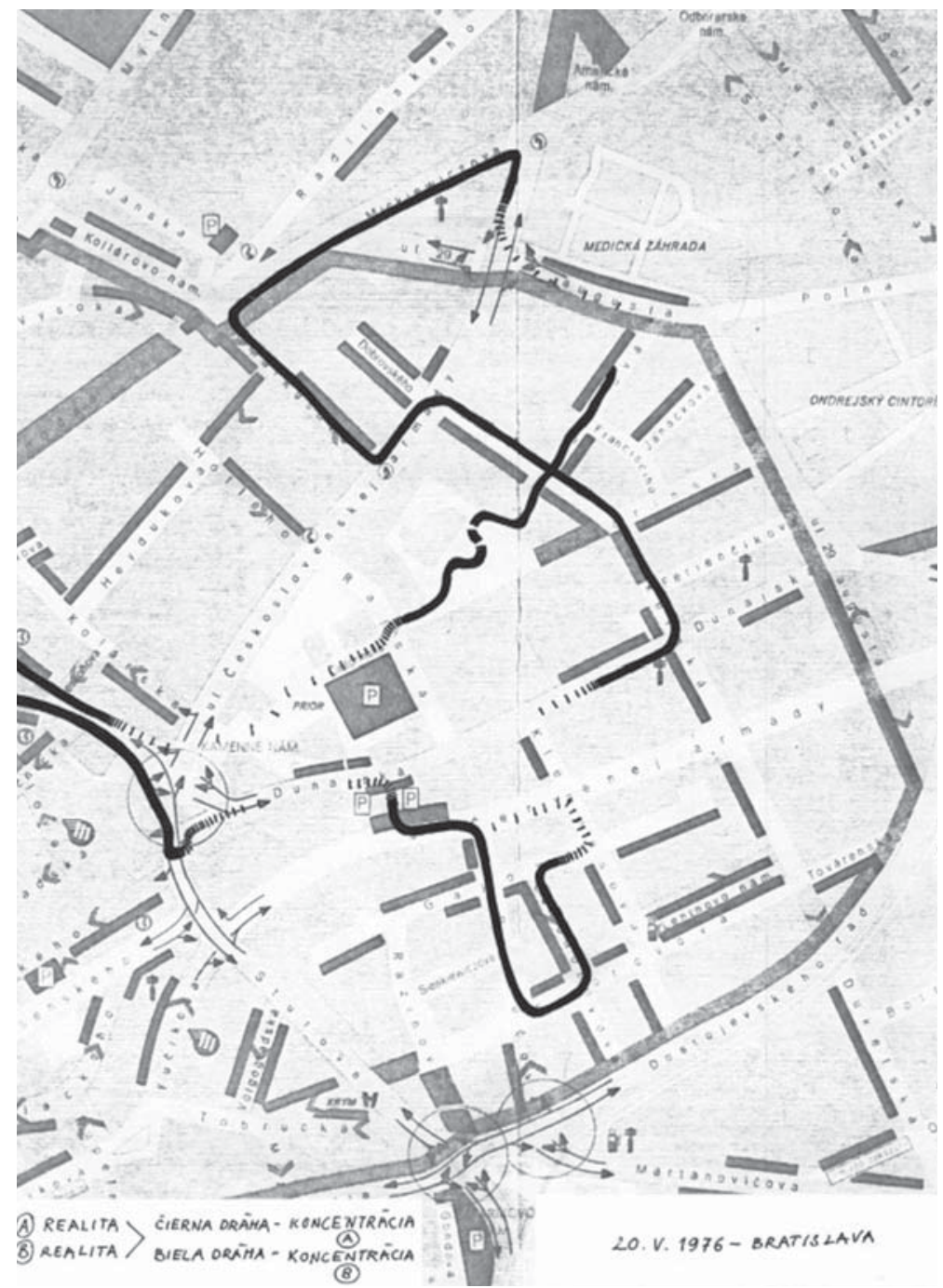

Source: Artist's archive

On 20 May 1976, Durček realized Prechádzka (Walk) in Bratislava’s centre, by marking his route on a map. A black line (A-concentration) represents the meditative route, a stroll during which the artist concentrated on his own introspection. A white line (B-concentration) documents where he perceived his surroundings. The map also captures sites where he shifted from the mental environment to the urban exterior. The walk, limited in time (1 hour) is a passage through the city and through his own mental space. As he mentions himself: 
he walked through Bratislava and through himself. Durček's map represents the situation, though not in the sense of a spatial interweaving of a situationist map. Here there is no disintegration and recreation of (mental) space, but rather a concentration on existing space (even in its stereotype or uniformity). The perception of a well-known city and its spatial relationships is brought to life not so much by the radical reforming of an everyday walk as by a divergence in its undertaking, and the "switching" between concentrated introspection and full-fledged perception of the city streets. In one phase he lets the city's reality and other walkers act on him, and in the other meditative phase he focuses on a "circumvention" and a quest for his own centre.

We find the use of documentation on a hiker's map of Bratislava in an action conceived by the theoretician and occasional artist Radislav Matuštík, Staking Out the Claim (1982), which was part of the landscape interventions by the alternative art society Terén (1982-87). This action consisted of a hike through the Carpathian hills around Bratislava, including some peripheral parts of town (such as Dúbravka, Krasňany, and Rača). The whole area is delineated by a set of violin tuning pins stuck into the terrain, representing stations that alternate between intact and cultivated sites (Matuštík 2000: 16-19). The action had two phases separated by a month (the first phase Opening [2 June 1982], the second Inspection [1 July 1982]), and concluded with a vista of the staked-out territory, which served likewise as a revision and recollection of this zone as "appropriated" by one's own body. Staking Out the Claim works with visual recording through the map, which copies the path and the sites where the pins were placed. The photography documenting the action's course shows how the pins were placed in various places (including trees, light fixtures, a bridge, an electrical circuit box, etc). The resulting map records the hike as a system of the ensuing experience, and the embellishment of nature and city by a light intervention. It corroborates reality with a topographically recorded plan. The action left behind a notation, on which it is possible to create more and new hikes. The symbolic aspect, present in the use of the tuning pins and the instructions to remain silent, lies in the indication to concentrate fully on the environmental sounds and visual impulses.

As Ďrček moves about the urbanized town, Czech artist Milan Maur undertakes his own amblings in the countryside. In many ways his work is analogous to that of Miloš Šejn. Delicate, subtle work with natural materials, and a feel for the countryside's individual components as archetypal elements, together lead Maur to a sensitive and often intimate charting of nature's processes. Maur's interest lies not only in making hidden, understated phenomena visible (often employing conceptual drawing), but also in capturing aesthetic qualities that are immanently present in their very processuality. On 9 May 1988, he undertook an action documented only in a succinct text, announcing: "On May $9^{\text {th }}$ 1988, I went after the sun from dawn to dusk," with an open ring drawn on a map of Plzen, showing the artist's path. The symbolic pilgrimage from east to west, mimicking the sun's path through the sky, is recorded as a bare fact. The artist's motivation, the course of the action, what he experienced, and the fatigue from his trek all remain unsignified, and are represented only through written statements and the map's straightforward planimetrics. So this is a record of an action stripped of its artistic, aesthetic or emotional aspect, not taking in its individual determinants. 
Figure 10: Radislav Matuštík, Staking Out the Claim, 1982

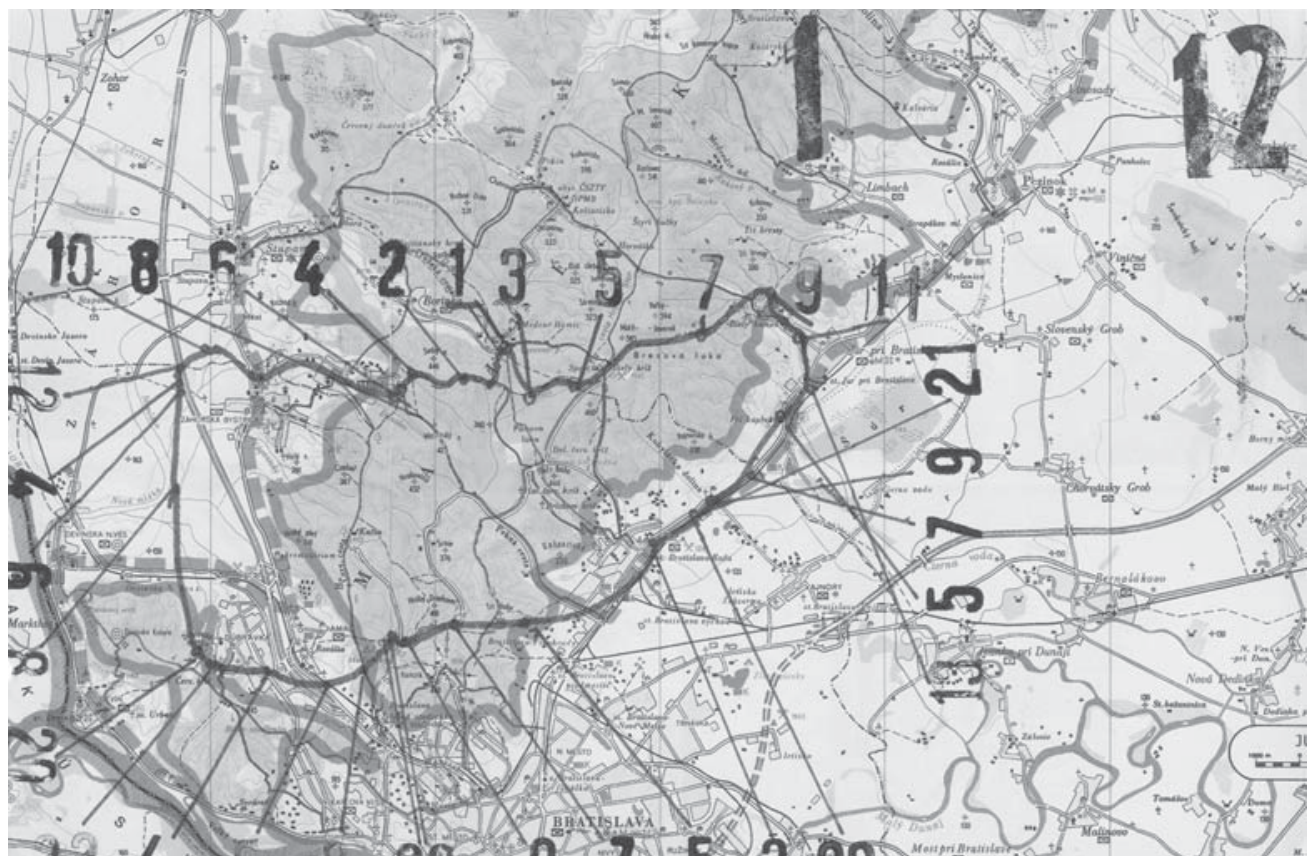

Source: Matuštík (2000)

In his documenting, Maur worked in a manner that by the 1970s was widespread in conceptual art. The Czech phenomenologist and psychologist Petr Rezek analyzed this mode of presentation among Prague's body-art community (K. Miler, P. Štembera, J. Mlčoch). A short piece and brief pithy commentary drives Rezek to the elementary question of why a given event is happening and why I speak of it. ${ }^{8}$ Rezek sees this as peculiar and indeterminate acting, free of any "why" or "because," which "just happens." In normal life, action aims at a goal, at a purpose. In the aforementioned action, the event is taken out of daily life thanks to its purposelessness, and it becomes a moment of passage, a festival. Rezek understands this acting as that which of itself shows itself, as phenomenality. It is a pure proceeding, which becomes the event's basis by opening up something new in the world. What is important for this means of presentation and communication the piece becomes a "reversion to mediality." In such a case, the map, which we have been accustomed to reading as a certain strategic, informational and orientating plan, becomes the supplementation of artefact; and an artefact is just an information-reproducing intention, an idea of the artist. The map plays a dual role:

8 In this context, Petr Rezek gives the example of Jan Mlčoch's action Výstup na Horu Kotel (26 April 1974) with its text "I climbed Mount Kotel, in bad weather, with wind and mist. I photographed the trip." (For a description and interpretation, see Rezek, 1982: 95-102.) 
as vector referring to an actual event, and as an anchoring or record of this event, which itself becomes a work of art in reflective gallery presentations.

An analogue to Milan Maur's work could be found in the "walking actions" of Richard Long. On 12-15 October 1969, Long made his Walking Sculpture. In Wiltshire in southern England, he started by creating an invisible square by walking, always recording precise times. Over the next three days, he increased the periphery, lengthening in direct proportion the time for the given square's "birth," until he had created a field of concentric (and invisible) squares in the landscape. The line sketched on the map thus made a kind of minimalist drawing in the countryside (Lippard 1973: 118). The "walking pieces" by the British artist Hamish Fulton are similar in character. One example is the series of actions of 14 paths from coast to coast (1982-89), with the artist bringing together selected parts of the British Isles' shoreline through his own walking, and drawing their routes onto a map.

Figure 11: Milan Maur, Journey to the Sun, 1988

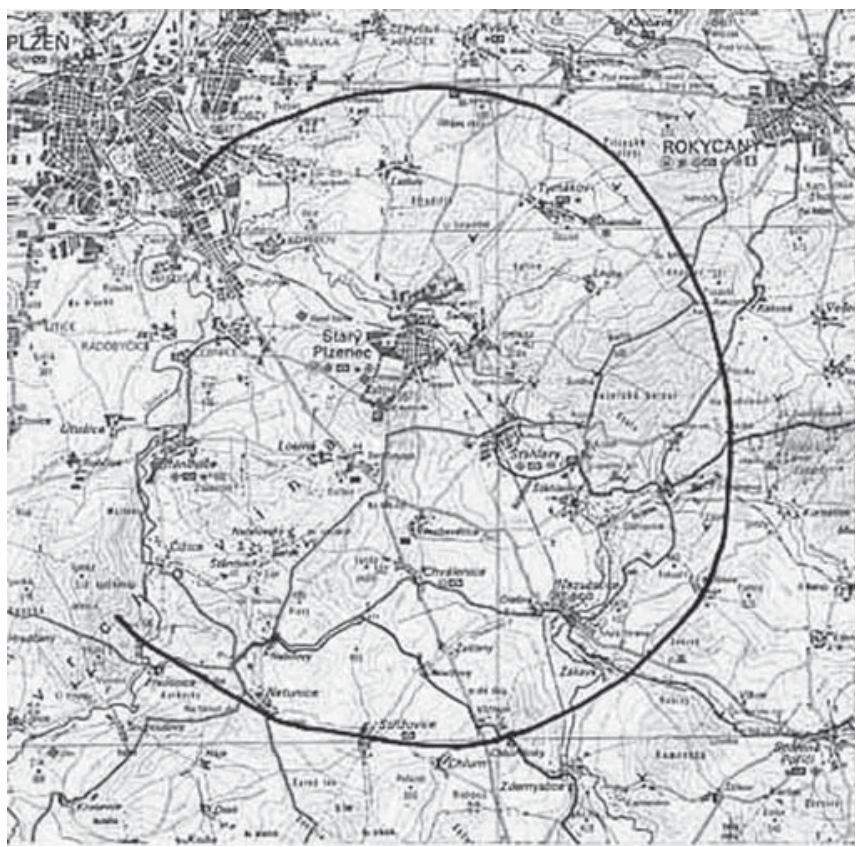

Source: http://www.milan-maur.cz/stranky/svetlo-a-stin.html

Given these examples of art cartography, the map takes on the character of instructions, or, on the contrary, of a transcript or record of activity. The map is a factor that incites to activity and participation, or it concentrates these situational acts into itself. In any case, a map is an expression of facts (and in our case of acts as well) realized in space and time, but always on the basis of a flat-layout schema. The map is a place, a grouping of positions that implies a certain indication of stability (Certeau 1996). It represents spatial and situational 
occurrences based on motion. It is a stabilization and codification of spatial alterations, but it becomes fully activated only through use; even as, for example, a street drawn on an urban plan changes in space thanks in part to pedestrians. In the terminology of M. de Certeau, a map is a text that has to be read (as in bringing to life and being interpreted by reading). In his L'Invention du Quotidien (1980), Certeau addresses the map motif as text. He maintains a map is a postulate of an itinerary (Certeau 1996). In conventional cartographic strategies using a map image, a place is contextualized in a situation, analogous to a map's relationship to a journey. The map is based on optical perception, while a journey is based on space-time proceedings. In artistic strategies (at least in those to which I refer in this study) there is an attempt to inter-relate proceedings and seeing, a convergence of processual and optical qualities. The map is no longer just "totalizing" a scene by bringing together elements disparate in character to create a "geographic state" of knowing (Certeau 1996: 85).

Figure 12: Richard Long, Hundred Mile Walking, 1971-1972

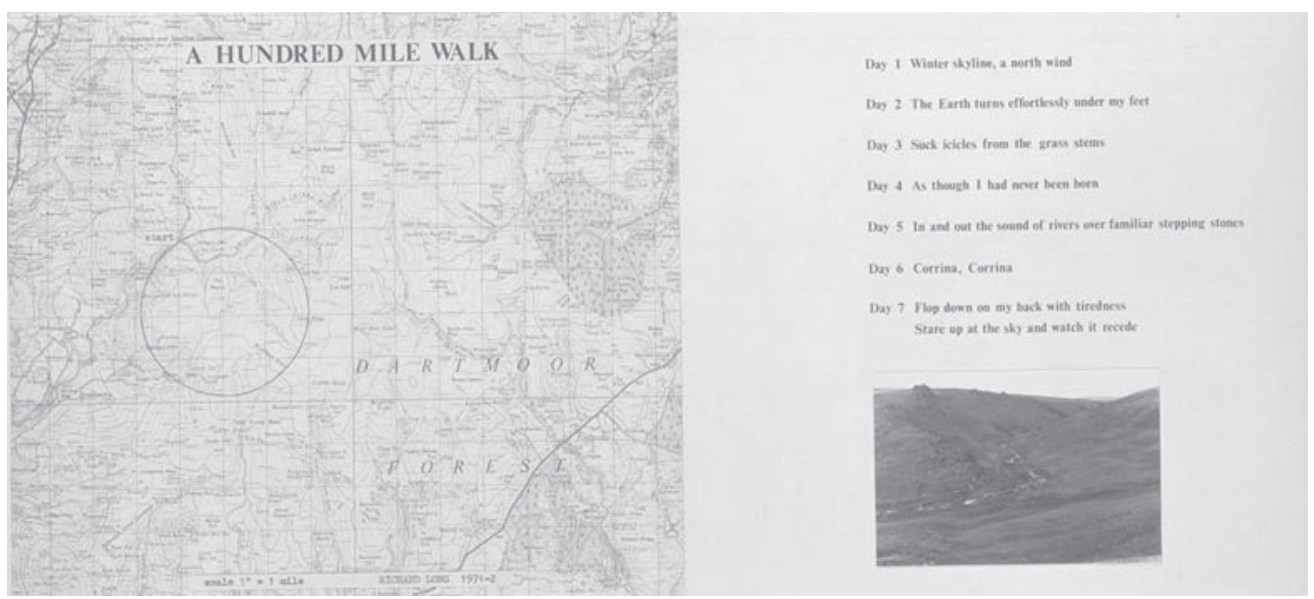

Source: https://www.tate.org.uk

The map, in the sense of these artists' approaches, becomes a demonstration of endeavour to go back to the journey's originator, to revive the narrator. The accent is on the subjective and an artistic resolution, on the interpreting of cartographic plotting. By emphasizing the "map's story," the meaning of the event that occurred as represented in the plan, it unambiguously refers to art cartography, or the use of the map within these works of art. In this system, the map transforms from a tracing to a rhizome, to an open structure that can be interpreted in such a way that both author and reader have a place of significance in its reading.

Roland Barthes long ago tackled the issue of how to read a map in his L'empire des signes (1964). He describes a way of getting oriented in the Japanese city of Tokyo that is a kind of urban itinerary. Finding one's way in the city comprises more than knowing and following the names of streets, sites and squares, in a marking-out of strategic points, i.e. 
a sketch or description of a route. There is no rationality in Tokyo's map, and articulation and heterogeneity of speech comes to the forefront. In an essay related to addresses, Barthes writes:

This city can be known only by an activity of an ethnographic kind: you must orient yourself in it not by book, by address, but by walking, by sight, by habit, by experience; here every discovery is intense and fragile, it can be repeated or recovered only by memory of the trace it has left in you... (Barthes 1983: 37)

\section{Conclusion}

In closing, we might note that, based on these examples of employing the map in (neo) conceptual art, the map is a system of symbols whose meaning is achieved only through use, through practice itself. It links a visual form, based on various map symbols, with the rhetorical (notional) nature of its expression. It is these elements that activate through artistic strategies employing the map, in a way (most particularly so when it comes to conceptual art) that compels us to reassess our notional apparatus. The philosopher Petr Kot'átko characterizes conceptual art as something that creates a situation that denies its audience the accustomed use of their notional apparatus, or fixed means of assessing experience or interpretational habits (Kot'átko 2011). The significance of using the map in art cartography is based not on getting oriented in space, but on the ability to localize objects that are expressed in a generalized manner. Above all else, it is a symbolic use of a graphic diagram of space, with the map's functionality representing spatial or social relationships. It becomes an appropriation of the visual as a form of code, which remains present and understandable within the user's practice. Thus art cartography is no longer a bringing together of the map's surface with a real territory, but rather a restructuring of mental schemas. It is an expression of a personal stance. The way the artist uses the map in the work occurs through diverse models of appropriation, negation, relativization, and interpretation, with relation to the media, to use or abuse of the map's symbolic function, or with relation to artistic interpretation. The map may become an incentive for situational practice or to participation, just as it may codify an already complete action.

In this text, of central interest to me has been the use of the map on two basic levels: the map as a result (record) of a mental or physical process, and the map as a document of an activity that was part of spatial practice in a specific territory. In both these models, the fundamental moment was that of assuming a space by means of its activation: by taking a walk. Walking is an elemental component of appropriating space, of creating experiential knowledge of an environment. It is the basis for creating a map, with all its consummation and fulfilment. In the context of this study, walking is the deconstruction of the traditional cartographic map, and a shift toward an artist's (conceptual) work, which refers to the meaning of a space-time event. 


\section{Ĺterature}

AUGÉ, Marc. 1999. Antropologie současných světů. Brno: Atlantis.

BARTHES, Roland. 1983. Empire of Signs. Translated by Richad Howard. New York: Hill and Wang Publishers.

BEST, Steven and Douglas KELLNES. 2008. "Debord a postmoderní obrat: nové etapy spektáklu." Sešit pro teorii, umění a príbuzné zóny 2(4-5): 74-101.

BIANCHI, Paolo and Sabine FOLIE, eds. 1997. Atlas Mapping. Wien: Verlag Turia + Kant.

CERTEAU, Michel de. 1984. "Walking in the City." In The Practice of Everyday Life. Translated by Steven Rendall. Los Angeles: University of California Press.

CERTEAU, Michel de. 1996. "Vynalézání každodennosti." In Cahiers du Cefres 10, Antologie francouzkých společenských věd. Téma: Město, edited by Alban Bensa and Václav Hubinger. Prague: Francouzský ústav pro výzkum ve společenských vědách.

ČARNÁ, Daniela and Lucia GREGOROVÁ. 2011. Mapy/Maps. Umelecká kartografia v strednej Európe. Bratislava: GMB, SNG.

DEBORD, Guy. 1958. "Theory of the Dérive.” Translated by Ken Knabb. Internationale Situationniste, December, 2. Accessed January 19, 2015 (http://www.cddc.vt.edu/sionline/si/theory.html).

DEBORD, Guy. 2006. The Society of the Spectacle. Translated by Donald Nicholson-Smith. New York: Zone Books.

DELEUZE, Gilles and Félix GUATTARI. 2005. A Thousand Plateaus. Translated by Brian Massumi. Minneapolis, MN: University of Minnesota Press.

FLUSSER, Vilém. 2001. Do universa technických obrazů. Prague: OSVU.

FOUCAULT, Michel. 2004. Dozerat' a trestat'. Bratislava: Kalligram.

GODFREY, Tony. 1998. Conceptual Art. London: Phaidon Press.

GOFFMAN, Erving. 1999. Všichni hrajeme divadlo. Prague: Nakladatelství studia Ypsilon.

HARLEY, John Brian. 2008. "Maps, Knowledge, and Power." Pp. 185-212, in Czech translation, in Možnosti vizuálních studií, edited by Marta Filipová and Matthew Rampley. Brno: Barrister \& Principal.

KOLÁŘ, Jiří. 2007. Návod k upotřebení. Prague: Dokořán.

KOSUTH, Joseph. 1991. Art After Philosophy and After: Collected Writings, 1966-1990. Cambridge: MIT Press.

KOŤÁTKO, Petr. 2011. “Umělecké dílo konceptuální (Radikální konceptualismus v literatuře).” Sešit pro umění, teorii a př́buzné zóny 5(10): 43-57.

LIPPARD, Lucy, R. 1973. Six Years: The Dematerialization of the Art Object from 1966 to 1972. Los Angeles: University of California Press.

MAGID, Václav. 2008. "Konstruovaná situace a její okamžik v čase.” Sešit pro teorii, uměni a př́buzné zóny 2(4-5): 32-60.

MATUŠTÍK, Radislav. 2000. Terén - alternatívne akčné zoskupenie 1982-1987. Bratislava: SCCA.

MONMONIER, Mark. 2000. Proč mapy lžou. Brno: Computer Press.

PEREC, Georges. 1997. Species of Spaces and Other Pieces. Translated by John Sturrock. New York: Penguin Books.

PRAVDA, Ján. 2003. Stručný lexikón kartografie. Bratislava: Veda.

REZEK, Petr. 1982. Tělo, věc a skutečnost v současném umění. Praha: Jazzpetit.

STORR, Robert, ed. 1994. Mapping. New York: Museum of Modern Art.

THOREAU, Henry David. Walking. Accessed January 19, 2015 (http://www.gutenberg.org/files/1022/ 1022.txt).

TOKARCZUK, Olga. 2008. Běguni. Brno: Host. 
UNGAR, Simon. 2005. "Psychogeography." In Encyclopedia of the City, edited by Roger W. Caves. London: Routledge.

VALOCH, Jiří. 1986. Miloš Šejn - fotografie, kresby, knihy. Brno: Dům umění města Brna.

WATSON, Ruth. 2009. "Mapping and Contemporary Art.” The Cartographic Journal 46(4): 293-307.

\section{Author}

Ján Kralovič works as a researcher and art historian at the Academy of Fine Arts in Bratislava - the AFAD (Section of Visual and Cultural Studies). His current research deals with the unofficial, non-gallery exhibition presentations made by artists during the normalization period in (Czecho-)Slovakia. At the AFAD he teaches the history of Slovak art in the 20th century and leads workshops on theory and interpretation of works of art. His professional publications are devoted to phenomenological philosophy, the interdisciplinary overlap between film and literature, as well as the specific problems of action art and urban space. Contact: jan.kralovic@vsvu.sk 